Journal of Marine Science and Technology; Vol. 16, No. 3; 2016: 244-254

DOI: $10.15625 / 1859-3097 / 16 / 3 / 7821$

http://www.vjs.ac.vn/index.php/jmst

\title{
EFFECT OF OPERATING PARAMETERS OF HYDRAULIC FRACTURING ON FRACTURE GEOMETRY AND FLUID EFFICIENCY IN OLIGOCENE, OFFSHORE VIETNAM
}

\author{
Nguyen Huu Truong \\ Petro Vietnam University, Vietnam \\ E-mail: truongbiennho@gmail.com
}

Received: 26-2-2016

\begin{abstract}
In the past decades, a large amount of oil production in the Cuu Long basin was mainly exploited from the basement reservoir, oil production from the Miocene sandstone reservoir and a small amount of oil production from the Oligocene sandstone reservoir. Many discovery wells and production wells in lower Tra Tan and Tra Cu of Oligocene sandstone had high potential for oil and gas production and reserve where the average reservoir porosity was in range of $10 \%$ to $18 \%$, and reservoir permeability was in range of $0.1 \mathrm{md}$ to $5 \mathrm{md}$. Due to high reservoir heterogeneity, complication and complexity of the geology, high closure pressure was up to 7,700 psi. The problem in the Oligocene reservoir is very low fracture conductivity due to low conductivities among the fractures of the reservoirs. The big challenges deal with this problem of hydraulic fracturing stimulation to improve oil and gas production that is required of the study. In this article, the authors have presented the effects of operating parameters as injection time, injection rate, and leak-off coefficient of hydraulic fracturing based on the $2 D P K N-C$ fracture geometry account for leak-off coefficient, spurt loss in terms of power law parameters on the fracture geometry. By the use of design of experiments (DOE) and application of response surface methodology in the constraint of operating hydraulic fracturing parameter of the field experience, the effects plots are evaluated. In the recent years, from the successful application of the hydraulic fracturing stimulation for well completion in the Oligocene reservoir, this technology is often used to stimulate reservoir.
\end{abstract}

Key words: Operating parameters of hydraulic fracturing, the $2 D$ PKN-C fracture geometry, fluid efficiency.

\section{OLIGOCENE RESERVOIR DESCRIPTION}

Energy demand for oil and gas are increasing worldwide and energy supplies for the developing domestic economy is also rising in particular. In the past decades, hydraulic fracturing stimulation has been widely used in the petroleum industry for improving oil production which is to apply stimulation in the vertical well, multistage hydraulic fracturing in a horizontal well. In Vietnam, oil production rate in the Oligocene reservoir declined in a long time due to many reasons such as pressure of the reservoir decline as well as the decrease in oil production rate, the low reservoir permeability from $0.1 \mathrm{md}$ to $5 \mathrm{md}$, low reservoir porosity from $10 \%$ to $18 \%$, reservoir heterogeneity, complicated and complex reservoir. These problems in the reservoir lead to low conductivity among the fractures of the reservoir. They are solved by stimulating the reservoir of hydraulic fracturing stimulation. In 
Cuu Long basin, there are three pay zones of oil production that consist of the basement reservoir, Miocene sandstone reservoir, and the Oligocene sandstone reservoir. The previous report has estimated the amount of oil production reserves that can be exploited from the basin about 5600 million to 5950 million barrels of oil equivalent. That is equal to potential hydrocarbon reserves about 22.4 billion to 23.8 billion of oil equivalents. At the basin, $70 \%$ of oil production is exploited in the fracture basement reservoir, $18 \%$ oil production in the Oligocene reservoir (1033 million barrels of oil reserves) and $12 \%$ of oil production in the Miocene reservoir. On the other hand, total amount of oil production in Oligocene reservoir in the White Tiger oil field is only exploited of 76.7 million barrels of oil which is equal to $4.6 \%$ of total amount of oil production in the White Tiger and equal to $7.4 \%$ of oil in the Oligocene reservoir. These layers in the Oligocene reservoir include Tra Tan of Oligocene C, Oligocene D and Oligocene E, Tra $\mathrm{Cu}$ in the Oligocene $\mathrm{F}$. In this article, the authors have mentioned the Oligocene $\mathrm{E}$ reservoir and have presented the effects of operating parameters of hydraulic fracturing on the fracture geometry as fracture half-length, fracture width during fracturing operation in the Oligocene reservoir. The result of the research is very useful in order to select the good operating parameters of hydraulic fracturing in the Oligocene stimulation. In the future work, the authors will present the combined operating parameters of hydraulic fracturing and other parameters that cannot be controlled such as reservoir permeability, fracture height, reservoir porosity affecting to the economic performance.

\section{FRACTURING FLUID SELECTION AND FLUID MODEL}

Ideally, the fracturing fluid is compatible with the formation of rock properties, fluid flow in the reservoir, reservoir pressure, and reservoir temperature. Fracturing fluid generates pressure in order to transport proppant slurry and open fracture, produce fracture growth and fracture propagation during pumping, also fracturing fluid should minimize pressure drop alongside and inside the pipe system in order to increase pump horsepower with the aim of increasing a net fracture pressure to produce more and more fracture dimension. In fracturing fluid system, the breaker additive would be added to the fluid system to clean up the fractures after treatment. Due to high temperature of Oligocene $\mathrm{E}$ reservoir the Dowell YF 660 high temperature (HT) without breaker with $2 \% \mathrm{KCl}$ is selected for fracturing fluid system. To predict precisely the fracture geometry as fracture half-length, fracture width during pumping, the power law fluid model would be applied in this study. Then the most fracturing fluid model is usually given by:

$$
\tau=K \gamma^{n}
$$

Where: $\tau$ - shear stress, $\gamma$ - shear rate, $K$ consistency coefficient, $\mathrm{n}$ - rheological index as flow behavior index of non-dimensional model but related to the viscosity of the nonNewtonian fracturing fluid model (Refer to Valko's \& Economides, 1995) [1].

The power law model can be expressed by:

$\log \tau=\log K+n \log \gamma$

$$
\begin{gathered}
\text { Slope }=\left[\left(N \sum X Y\right)-\left(\sum X \sum Y\right)\right] /\left[\left(\sum X^{2}\right)-\left(\sum X\right)^{2}\right] \\
\text { Intercept }=\left(\sum Y-n \sum X\right) / N
\end{gathered}
$$

Where: $X=\log \gamma, Y=\log \tau$, and $N=$ Data number. Thus $\mathrm{n}=$ Slope and $K=\operatorname{Exp}$ (Intercept).

$\log \tau=\log K+n \log \gamma$

$$
\begin{gathered}
\text { Slope }=\left[\left(N \sum X Y\right)-\left(\sum X \sum Y\right)\right] /\left[\left(\sum X^{2}\right)-\left(\sum X\right)^{2}\right] \\
\text { Intercept }=\left(\sum Y-n \sum X\right) / N
\end{gathered}
$$

Where $\mathrm{X}=\log \gamma, \mathrm{Y}=\log \tau$, and $N=$ Data number. Thus $\mathrm{n}=\mathrm{Slope}$ and $\mathrm{K}=\mathrm{Exp}$ (Intercept). 
Table 1. Oligocene reservoir data of $X$ well, offshore Vietnam [2]

\begin{tabular}{lcc}
\hline \multicolumn{1}{c}{ Parameter } & Value \\
\hline Target fracturing depth, ft. & 12,286 \\
Reservoir drainage area, acres & 122 \\
Reservoir drainage radius, ft. & 1,300 \\
Wellbore radius, ft. & 0.328 \\
Reservoir height, ft. & 72 \\
Reservoir porosity & 0.121 \\
Reservoir permeability, md & 0.5 \\
Reservoir fluid viscosity, cp & 1.5 \\
Oil formation volume factor, RB/STB & 1.4 \\
Total compressibility, psi $^{-1}$ & $1.00 \times 10^{-5}$ \\
Young's modulus, psi & $5 \times 10^{6}$ \\
Sandstone Poisson's ratio & 0.25 \\
Initial reservoir pressure, psi & 4,990 \\
Reservoir temperature, ${ }^{0} \mathrm{~F}$ & 266 \\
Oil API & 36.7 \\
Gas specific gravity & 0.79 \\
Bubble point pressure, psi & 1,310 \\
Flowing bottom hole pressure, psi & 3,500 \\
Closure pressure, psi & 7,700 \\
\hline
\end{tabular}

Table 2. Hydraulic fracturing parameters [2]

\begin{tabular}{|c|c|}
\hline Parameter & Value \\
\hline Fracture height, $h_{\mathrm{f}}, \mathrm{ft}$. & 72 \\
\hline Sandstone Poisson's ratio & 0.25 \\
\hline Leak-off coefficient, $\mathrm{ft} / \mathrm{min}^{0.5}$ & 0.003 \\
\hline Young's modulus, psi & $3.00 \times 10^{6}$ \\
\hline Injection rate, bpm & $18 \mathrm{bpm}$ to $22 \mathrm{bpm}$ \\
\hline Injection time, $\min$ & $\begin{array}{l}60 \text { minutes to } \\
120 \text { minutes }\end{array}$ \\
\hline Spurt loss, gal/ft ${ }^{2}$ & 0 \\
\hline $\begin{array}{l}\text { Proppant concentration end of } \\
\text { job, ppg }\end{array}$ & 8 \\
\hline Flow behavior index, $\mathrm{n}$ & 0.69 \\
\hline Consistency index, K, lbf.s $\mathrm{s}^{\mathrm{n}} / \mathrm{ft}^{2}$ & 0.04 \\
\hline \multicolumn{2}{|c|}{$\begin{array}{l}\text { Fracturing fluid type: Dowell YF } 660 \mathrm{HT} \text { without breaker } \\
\text { with } 2 \% \mathrm{KCl}\end{array}$} \\
\hline
\end{tabular}

\section{PROPPANT SELECTION}

In order to select proppant, the proppant would be selected correctly as proppant type, proppant size, proppant porosity, proppant permeability and proppant conductivity, strength proppant under effective stress pressure of the fracture in order to evaluate precisely the fracture conductivity of the fractures with proppant damage factor effect. Proppant is used to open fractures and maintain the open fractures for a long time in high fracture conductivity while pump pressure is shut down and fracture begins to close due to effective stress and overburden pressure. The idea for proppant selection would be stronger to resist the crush, erosion, and corrosion in the well. Due to closure pressure up to $7,700 \mathrm{psi}$, proppant should be selected as Carbolite ceramic proppant with proppant size 20/40 (Refer to Nolte and Economides) [3].

Table 3. CARBO-LITE ceramic intermediate strength proppant, $20 / 40$

\begin{tabular}{lc}
\hline \multicolumn{1}{c}{ Parameters } & Values \\
\hline Proppant type & $20 / 40$ CARBO-Lite \\
Density, $\rho_{p}$ & 2.71 \\
Strength & Intermediate \\
Average proppant diameter & 0.0287 \\
Proppant porosity $\phi_{\mathrm{p}}, \%$ & 35 \\
Proppant pack permeability, $\mathrm{mD}$ & 600 \\
Proppant conductivity at closure & $6600 \mathrm{mD} . \mathrm{ft}$ \\
pressure of 2lb/ft & \\
Fracture conductivity damage & 0.5 \\
factor & \\
\hline
\end{tabular}

\section{FRACTURE GEOMETRY MODEL}

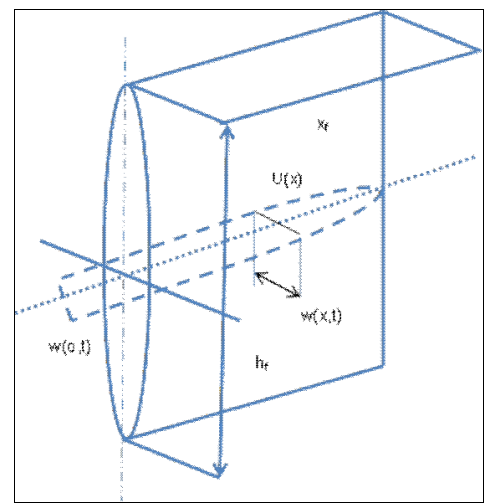

Fig. 1. The PKN fracture geometry

In this study, the 2D PKN fracture geometry model (Two dimensional PKN; Perkins and Kern, 1961; Nordgren, 1972) [4, 5] in figure 1 is used to present the significant fracture geometry of hydraulic fracturing stimulation for low permeability, low porosity and poor conductivity as Oligocene E reservoir, that requires the fracture half-length of the fracture design and precise evaluation of the fracture geometry. After incorporation of carter 
Solution II, the model known as 2D PKN-C (Howard and Fast, 1957) [6] had incorporated the leak-off coefficient, in terms of consistency index $(\mathrm{K})$, flow behavior index (n), injection rate, injection time, fluid viscosity, fracture height. The model detail referred to (Valko's and Economides, 1995) [1] is shown in table 3.

The maximum fracture width in terms of the power law fluid parameters is given by:

$$
\mathrm{W}_{f}=9.15 \frac{1}{2 n+2} \times 3.98 \frac{n}{2 n+2}\left(\frac{1+(\pi-1) n}{n}\right)^{\frac{n}{2 n+2}} K^{\frac{1}{2 n+2}} \times\left(\frac{\left(q_{i} / 2\right)^{n_{h} h_{f}^{-} n_{x f}}}{E^{\prime}}\right)^{\frac{1}{2 n+2}}
$$

Where: $E^{\prime}$ is the plane strain in psi, $E^{\prime}=\frac{1}{1-v^{2}}$;

$\mathrm{n}$ is the flow behavior index (dimensionless); $K$ is the consistency index $\left(\mathrm{Pa} \cdot \sec ^{\mathrm{n}}\right) ; v$ is in the Poisson's ratio; $\mu$ is in Pa.s. (Rahman, M. M., 2002), the power law parameters are correlated with fluid viscosity of fracturing fluid as [7]:

$$
\begin{gathered}
n=0.1756 \times(\mu)^{-0.1233} \\
K=47.880 \times(0.5 \mu-0.0159)
\end{gathered}
$$

By using the shape factor of $\pi / 5$ for a $2 \mathrm{D}$ PKN fracture geometry model, the average fracture width $\mathrm{w}_{\mathrm{a}}$ is given by $\pi / 5 \times \mathrm{w}_{\mathrm{f}}$ as equation.

$$
\mathrm{W}_{a}=\frac{\pi}{5} \times 9.15^{\frac{1}{2 n+2}} \times 3.98^{\frac{n}{2 n+2}}\left(\frac{1+(\pi-1) n}{n}\right)^{\frac{n}{2 n+2}} K^{\frac{1}{2 n+2}} \times\left(\frac{\left(q_{i} / 2\right)^{n_{h_{f}^{l-n} n_{f f}}}}{E^{\prime}}\right)^{\frac{1}{2 n+2}}
$$

Carter solution II formulated material balance in terms of injection rate to the well. At the injection time $t_{e}$, the injection rate enters one wing of the fracture area, the material balance presents the relationship between injection rate (q) of the total fracture volume with fluid volume losses to fractures. The material balance is presented as equation below.

$$
q=2 \int_{0}^{t} \frac{C_{L}}{\sqrt{t-\tau}} \times\left(\frac{d A}{d \tau}\right) d \tau+2 S_{p} \times \frac{d A}{d t}+\mathrm{w} \times \frac{d A}{d t}+A \frac{d \mathrm{w}}{d t}
$$

By an analytical solution for constant injection rate (q), Cater solved the material balance that gives the fracture area for two wings as:

$$
A(t)=\frac{\mathrm{w}_{a}+2 S_{p}}{4 C_{L}^{2} \pi} \times q\left[\exp \left(\beta^{2}\right) \operatorname{erfc}(\beta)+\frac{2 \beta}{\sqrt{\pi}}-1\right]
$$

Hence fracture half-length with the fracture surface area $A(t)=2 x_{f} h_{f}$ is given by

$$
x_{f}=\frac{\mathrm{w}_{a}+2 S_{p}}{4 C_{L}^{2} \pi} \times \frac{q}{2}\left[\exp \left(\beta^{2}\right) \operatorname{erfc}(\beta)+\frac{2 \beta}{\sqrt{\pi}}-1\right]
$$

Where: $\beta=\frac{2 C_{L} \sqrt{\pi t}}{\mathrm{w}_{a}+2 S_{p}}$

Equation (6) presents the fracture halflength during proppant slurry injection into the fractures and this equation also describes the fracture propagation alongside the fractures with time. Accordingly, the fracture half-length depends on several parameters as injection rate $(q)$, injection time $(t)$, leak-off coefficient $\left(C_{L}\right)$, spurt loss $\left(S_{p}\right)$, fracture height $\left(h_{f}\right)$, and the average fracture width $\left(\mathrm{w}_{\mathrm{a}}\right)$. From the close of equation (6), it can be easy to determine the valuable fracture half-length by using iterative calculation method. The PKN fracture geometry model is presented in figure 1 .

\section{MATERIAL BALANCE}

Cater solved the material balance to account for the leak-off coefficient, spurt loss, injection rate, injection time, and in terms of power law parameters of flow behavior index of $\mathrm{n}$ and consistency index of $K$. Proppant 
slurry is pumped to the well under high pressure to produce fracture growth and fracture propagation. Therefore, the material balance is expressed as equation: $V_{i}=V_{f}+V_{l}$, where $V_{i}$ is the total fluid volume injected to the well, $V_{f}$ is the fracture volume that is required to stimulate reservoir, and $V_{l}$ is the total fluid losses to the fracture area in the reservoir. The fracture volume, $V_{f}$, is defined as two sides of the symmetric fracture of
$V_{f}=2 x_{f} h_{f} w_{a}$ [1]. The fluid efficiency is defined by $V_{f} / V_{i}$. In 1986 , Nolte proposed the relationship between the fluid volumes injected and pad volume as well as a model for proppant schedule. At the injection time $t$, the injection rate enters into two wings of the fractures with $\mathrm{q}$, the material balance presented as the constant injection rates $\mathrm{q}$ is the sum of the different leak-off flow rate plus fracture volume [8] as:

$$
q=2 \int_{0}^{t} \frac{C_{L}}{\sqrt{t-\tau}} \times\left(\frac{d A}{d \tau}\right) d \tau+2 S_{p} \times \frac{d A}{d t}+\mathrm{w} \times \frac{d A}{d t}+A \frac{d \mathrm{w}}{d t}
$$

The fluid efficiency of fractured well of the post fracture at the time $(t)$ is given by:

$$
\eta=\frac{\mathrm{w}_{a} h_{f} x_{f}}{q t} \text { or } \eta=\frac{\mathrm{w}_{a} h_{f}\left(\mathrm{w}_{a}+2 S_{p}\right)}{4 \pi C_{L}^{2} t} \times\left[\exp \left(\beta^{2}\right) \operatorname{erfc}(\beta)+\frac{2 \beta}{\sqrt{\pi}}-1\right]
$$

Where: $\beta=\frac{2 C_{L} \sqrt{\pi t}}{\mathrm{w}_{a}+2 S_{p}}$, and $C_{L}$ is the leak-off coefficient in $\mathrm{ft} / \mathrm{min}^{0.5}, \mathrm{w}_{\mathrm{a}}$ is the average fracture width in the fractures in inch, $S_{p}$ is the spurt loss in the fractures in $\mathrm{gal} / \mathrm{ft}^{2}$.

\section{CENTRAL COMPOSITE DESIGN (CCD)}

The design of experiments (DOE) techniques is commonly used for process analysis and the models are usually the full factorial, partial factorial, and central composite rotatable designs. An effective alternative to the factorial design is the central composite design (CCD), which was originally developed by Box and Wilson and improved by Box and Hunter in 1957. The CCD was widely used as a three-level factorial design, requires much fewer tests than the full factorial design, and has been provided to be sufficient as describing the majority of steady state products of response. Currently, CCD is one of the most popular classes of design used for fitting second-order models. The total number of tests required for is $2^{k}+2 k+\mathrm{n}_{0}$, including the standard $2^{k}$ factorial points with its origin at the center, $2 k$ points fixed axially at a distance, say $\beta\left(\beta=2^{\mathrm{k} / 4}\right)$, from the center to generate the quadratic terms, and replicate tests at the center $\left(\mathrm{n}_{0}\right)$, where $k$ is the number of independent variables. These operating parameters of the variables are named as injection rate, $X_{1}$, injection time, $X_{2}$, leak-off coefficient, $X_{3}$, presenting the total number of test required of the three variables of $2^{3}+(2 \times 3)+3=17$. In this experiment design, the center points were set at 3 and the replicates of zero value. Therefore, the three independent variables of the operating parameters of the CCD were shown in table 3 . The coded and actual levels of the dependent variables of each experiment design in the matrix column are calculated in table 4 . From table 4 , the experiment of design is conducted for obtaining the response [9].

Table 4. Three independent variables and their

\begin{tabular}{|c|c|c|c|}
\hline & \multicolumn{3}{|c|}{ Coded variable level } \\
\hline & Low & Center & High \\
\hline Variables symbol & -1 & 0 & 1 \\
\hline Injection rate, bpm & 18 & 19 & 20 \\
\hline Injection time, minutes & 60 & 90 & 120 \\
\hline $\begin{array}{l}\text { Leak-off coefficient, } \\
\mathrm{ft} / \mathrm{min}^{0.5}\end{array}$ & 0.003 & 0.005 & 0.007 \\
\hline
\end{tabular}
levels for central composite design (CCD) [9]

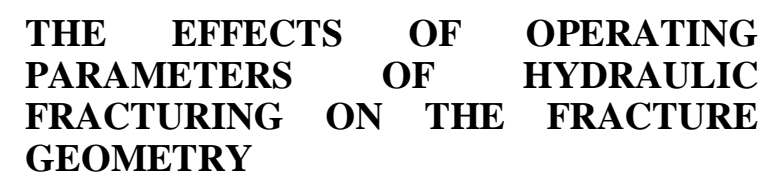


Currently, the hydraulic fracturing in the field can be divided into two types of parameters as operating parameters of hydraulic fracturing of the injection rate, injection time and leak-off coefficient at which these parameters are controlled from the surface and facilities and the rest of parameters that cannot be controlled as rock properties of young modulus, geological structure, reservoir porosity, reservoir permeability and fracture closure pressure and the stress regime of the fracture of normal fault stress regime, strike slip regime, reverse faulting stress regime. In this article, the authors have presented the operating parameters on fracture geometry of fracture half-length at the normal faulting stress regime that is the minimum horizontal stress as closure pressure of 7,700 psi. In this research, the recommended operating parameters is based on the field experience offshore Vietnam for the injection rate in the range of $18 \mathrm{bpm}$ to $22 \mathrm{bpm}$, injection time in the range of 60 minutes to 120 minutes, and the leak-off coefficient in the range of 0.003 $\mathrm{ft} / \mathrm{min}^{0.5}$ to $0.007 \mathrm{ft} / \mathrm{min}^{0.5}$. One of the most important operating parameters is the leak-off coefficient at which the leak-off coefficient has more effect on the fracture geometry as well as on the net present value. Current total leak-off coefficient is controlled by three mechanisms of rock compressibility, invaded zone, and wall building effect. In the three mechanisms, only one parameter can control of filtration viscosity of fracturing fluid system. Usually, the higher fracturing fluid viscosity as high polymer concentration of the fracturing fluid that is the same as high fracturing fluid density can decrease the wall building effect as the decrease in the total leak-off coefficient. In this research, the author proposed the fracturing fluid parameters and fluid properties as in the table 2 .

The model for overall leak-off coefficient was presented by (Williams, 1970 and Williams et al., 1979) [10-12] as:

$$
C_{l}=\frac{-\frac{1}{C_{c}}+\sqrt{\frac{1}{C_{c}^{2}}+4\left(\frac{1}{C_{v}^{2}}+\frac{1}{C_{\mathrm{w}}^{2}}\right)}}{2\left(\frac{1}{C_{v}^{2}}+\frac{1}{C_{\mathrm{w}}^{2}}\right)}
$$

Where: $C_{v}$ is the viscous fluid loss coefficient due to the filtration in $\mathrm{ft} / \mathrm{min}^{0.5} ; C_{w}$ is the wall building of fluid loss coefficient in $\mathrm{ft} / \mathrm{min}^{0.5} ; C_{c}$ is leak-off coefficient due to total compressibility in $\mathrm{ft} / \mathrm{min}^{0.5}$.

\section{THE EFFECTS OF THE INJECTION RATE ON THE FRACTURE GEOMETRY}

Figure 2 and figure 3 present the effect of the injection rate on the fracture half-length, fracture width. These figures demonstrates that when the increase in the injection rate changes from $18 \mathrm{bpm}$ to $22 \mathrm{bpm}$ to the well, there is the increase in the fracture half-length. Meanwhile, the injection rate decreases from $22 \mathrm{bpm}$ to 18 $\mathrm{bpm}$ there is also the decrease in the fracture half-length. This is because that the injection rate is directly proportional to the fracture halflength. This explains why the injection rate increases from $18 \mathrm{bpm}$ to $22 \mathrm{bpm}$, the fracture half-length increases. In which the fracture height is constant of $72 \mathrm{ft}$ during injection to the well and injection time is originated by the design of injection time with the fracture geometry of 2D PKN-C. Figure 2 has demonstrated when there is the increase in the injection rate, fracture half-length also increases. This is because that the fracture halflength is directly proportional to the fracture width. In the figure 4 presents the injection rate versus the fluid efficiency in terms of the 2D PKN-C fracture geometry model. The figure has illustrated that when the injection rate increases from $18 \mathrm{bpm}$ to $20 \mathrm{bpm}$, the fluid efficiency increases because the fracture volume is gradually higher than the total volume injected to the well as low fluid loss volume in the fractures. This leads to the increase in the fluid efficiency. Accordingly, the injection rate ranges from $20 \mathrm{bpm}$ to 22 bpm, the fluid efficiency decreases due to high injection rate to the well as high pressure injected into the wells. This leads to high total fluid loss volume into the fractures as narrow fracture volume of the material balance.

The relationship between the response of the fracture half-length, fracture width and fluid efficiency with these variables has been presented in equation 1 and equation 2 , respectively. 


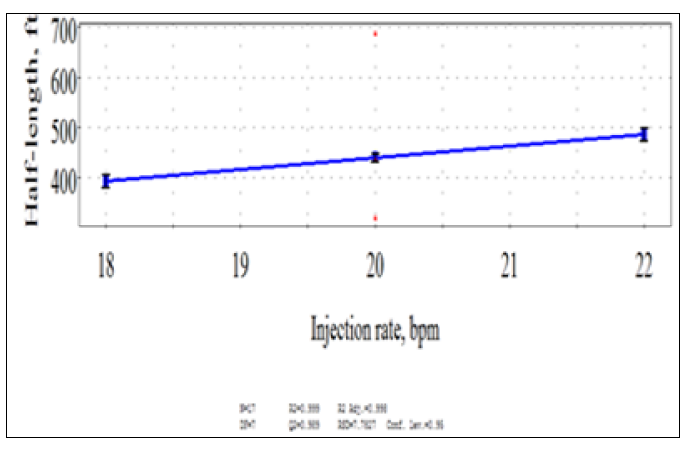

Fig. 2. The effect of injection rate on the fracture half-length

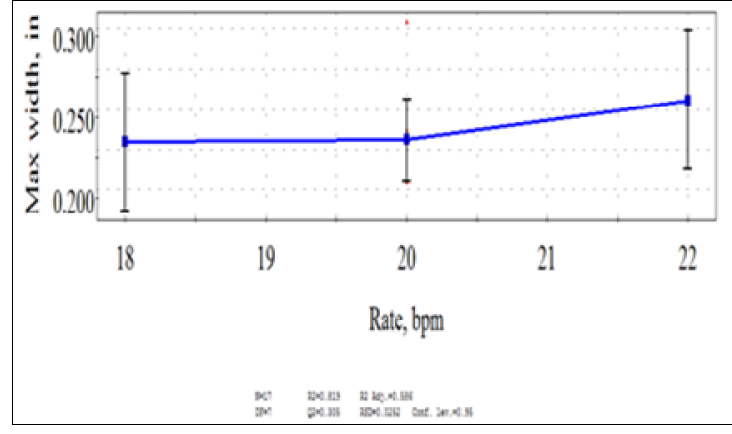

Fig. 3. The effect of injection rate on fracture width

Table 5. Independent variables and results of post fracture production with simulation observed by Central Composite Design (CCD) [13, 14]

\begin{tabular}{|c|c|c|c|c|c|c|c|c|c|}
\hline \multirow[b]{2}{*}{ Run } & \multicolumn{3}{|c|}{ Coded level of the variables } & \multicolumn{3}{|c|}{ Actual level of variables } & \multicolumn{3}{|c|}{ Response (simulation and observed) } \\
\hline & $\mathrm{X}_{1}$ & $\mathrm{X}_{2}$ & $x_{3}$ & $\begin{array}{l}\text { Injection } \\
\text { rate, } \\
\text { bpm }\end{array}$ & $\begin{array}{l}\text { Injection } \\
\text { time, } \\
\text { minutes }\end{array}$ & $\begin{array}{l}\text { Leak-off } \\
\text { coefficient, } \\
\mathrm{ft} / \mathrm{min}^{0.5}\end{array}$ & $\begin{array}{l}\text { Fracture-half } \\
\text { length, ft }\end{array}$ & $\begin{array}{l}\text { Fracture } \\
\text { width, in }\end{array}$ & $\begin{array}{c}\text { Fluid } \\
\text { efficiency, } \\
\%\end{array}$ \\
\hline 1 & -1 & -1 & -1 & 18 & 60 & 0.003 & 499.9 & 0.274 & 15 \\
\hline 2 & 1 & -1 & -1 & 22 & 60 & 0.003 & 602.7 & 0.301 & 16.3 \\
\hline 3 & -1 & 1 & -1 & 18 & 120 & 0.003 & 727.2 & 0.308 & 12.3 \\
\hline 4 & 1 & 1 & -1 & 22 & 120 & 0.003 & 879.0 & 0.340 & 13.4 \\
\hline 5 & -1 & -1 & 1 & 18 & 60 & 0.007 & 235.3 & 0.212 & 5.55 \\
\hline 6 & 1 & -1 & 1 & 22 & 60 & 0.007 & 286.1 & 0.237 & 6.1 \\
\hline 7 & -1 & 1 & 1 & 18 & 120 & 0.007 & 336.1 & 0.241 & 4.43 \\
\hline 8 & 1 & 1 & 1 & 22 & 120 & 0.007 & 409.2 & 0.209 & 4.86 \\
\hline 9 & -1 & 0 & 0 & 18 & 90 & 0.005 & 396.6 & 0.200 & 7.35 \\
\hline 10 & 1 & 0 & 0 & 22 & 90 & 0.005 & 481.6 & 0.280 & 8.04 \\
\hline 11 & 0 & -1 & 0 & 20 & 60 & 0.005 & 355.0 & 0.250 & 8.75 \\
\hline 12 & 0 & 1 & 0 & 20 & 120 & 0.005 & 510.4 & 0.280 & 13.92 \\
\hline 13 & 0 & 0 & -1 & 20 & 90 & 0.003 & 687.8 & 0.309 & 14 \\
\hline 14 & 0 & 0 & 1 & 20 & 90 & 0.007 & 321.5 & 0.242 & 5.1 \\
\hline 15 & 0 & 0 & 0 & 20 & 90 & 0.005 & 439.2 & 0.21 & 7.71 \\
\hline 16 & 0 & 0 & 0 & 20 & 90 & 0.005 & 439.2 & 0.21 & 7.71 \\
\hline 17 & 0 & 0 & 0 & 20 & 90 & 0.005 & 439.2 & 0.21 & 7.71 \\
\hline
\end{tabular}

Fracture half - length $=46.35 X_{1}+88.29 X_{2}-180.84 X_{3}-0.54 X_{1}^{2}$

$$
-6.94 X_{2}^{2}+65.011 X_{3}^{2}+8.91 X_{1} X_{2}-16.33 X_{1} X_{3}-34.96 X_{2} X_{3}
$$

Fracture width $=0.231465+0.0132 X_{1}+0.0104 X_{2}-0.0391 X_{3}-0.00756 X_{1}^{2}$

$$
+0.01744 X_{2}^{2}+0.02794 X_{3}^{2}-0.0065 X_{1} X_{2}-0.00825 X_{1} X_{3}-0.009 X_{2} X_{3}
$$

Fluid Efficiency $=8.48+0.407 X_{1}-0.279 X_{2}-4.496 X_{3}-1.36275 X_{1}^{2}+2.27725 X_{2}^{2}$

$$
+0.492253 X_{3}^{2}-0.04 X_{1} X_{2}-0.1775 X_{1} X_{3}+0.405 X_{2} X_{3}
$$

The equations 10, 11, and 12 have shown fracture half-length, fracture width, and fluid the relationship between the responses of the efficiency respectively with the variables that 
are presented in the detail of the figures 2, 3, and 4 . Moreover, the figure 5 can be divided into two regions. The first region presents the negative factor of these variables of $X_{1}, X_{2} . X_{3}$, $X_{1} . X_{3}, X_{2} . X_{2}$, and $X_{1} . X_{1}$. The increase of the factors results in the decrease in the fracture half-length. Accordingly, the decrease of the factors of the variables leads to the increase in the fracture half-length. The second region describes the positive factors of these variables of $X_{2}, X_{3} . X_{3}, X_{1}, X_{1} . X_{2}$ that effect the increase of fracture half-length. The increase of the positive factors of the fracture width model (11) leads to the increase of fracture width and increase of the fracture half-length because fracture width is directly proportional to the fracture half-length. The negative factors of these variables of $X_{3}, X_{2} . X_{3}, X_{1} . X_{3}, X_{1} . X_{1}, X_{1} . X_{2}$ effect the decrease of the fracture width. Figure 5 presents these factors of the variables affecting the fluid efficiency that shows the relationship between the variables and the fluid efficiency as presented in equation (12). The figure is also divided into two regions. The first region presents of the positive factors of $X_{2} . X_{2}$, $X_{3} . X_{3}, X_{1}, X_{2} . X_{3}$ that affect the increase of the fluid efficiency. Whereas, the second region presents the negative factors of these variables of $X_{2}, X_{3}, X_{1} . X_{1}, X_{1} . X_{2}, X_{1} . X_{3}$, that affect the decrease of the fluid efficiency. Especially, higher leak-off coefficient leads to low fluid efficiency. This is because the higher leak-off coefficient and higher total fluid volume loss in the fractures during proppant slurry injected to the well under high pressure lead to low fracture volume as understanding in the material balance.

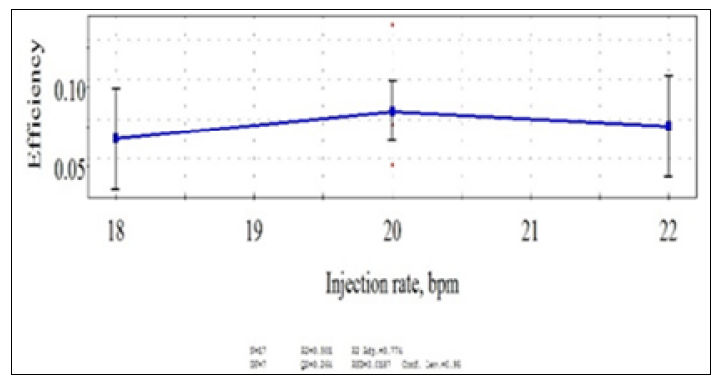

Fig. 4. The effect of injection rate on fluid efficiency

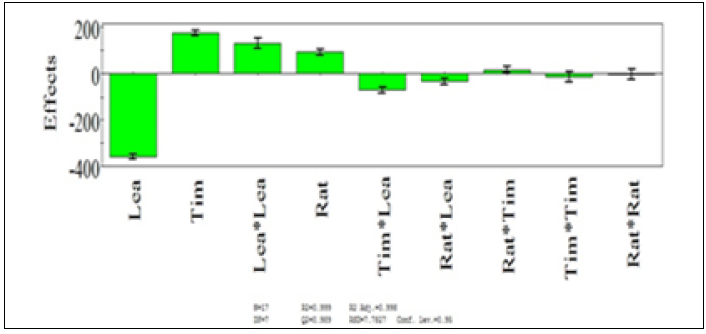

Fig. 5. The plots of the effect of these variables on the fracture half-length

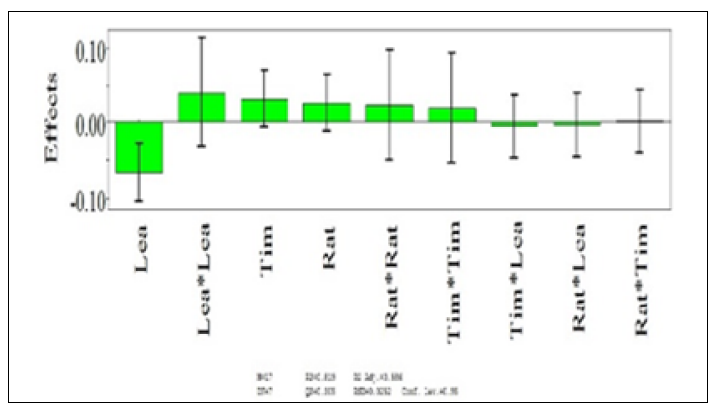

Fig. 6. The plots of the effect of these variables on the fracture width

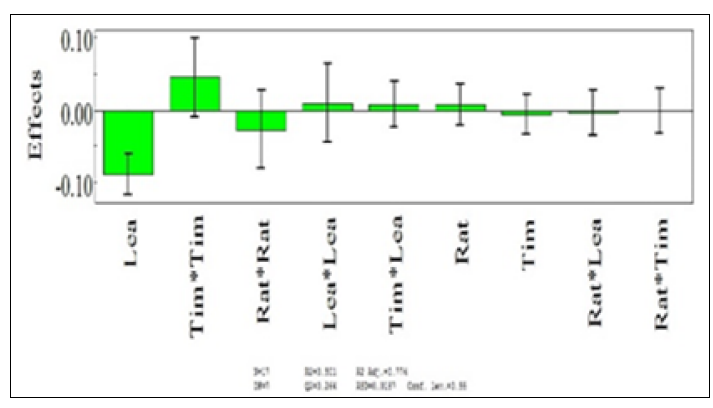

Fig. 7. The plots of the effect of these variables on fluid efficiency

\section{THE EFFECT OF THE INJECTION TIME ON THE FRACTURE GEOMETRY}

The effects of injection time on fracture half-length and fracture width are presented in figures 8 , and 9, respectively. This explanation is when injection time increases from 60 minutes to 120 minutes, the fracture half-length increases. Accordingly, the injection time increases, the fracture width increases gradually. This is because the injection time is directly proportional to fracture half-length. The more injection time results in long fracture 
half-length. Because the fracture width is directly proportional to the fracture half-length the more inection time leads to wider fracture width and longer fracture half-length. The long injection time leads to increase in the fracture volume besides the volume loss into the fractures. The relationship between the variables of $X_{1}, X_{2}, X_{3}$ and the response of the fracture geometry, fluid efficiency can be presented in equations (10) and (12).

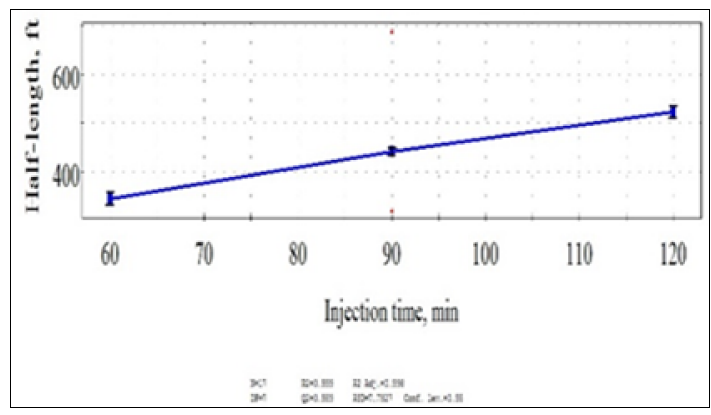

Fig. 8. The effect of the injection time on the fracture half-length

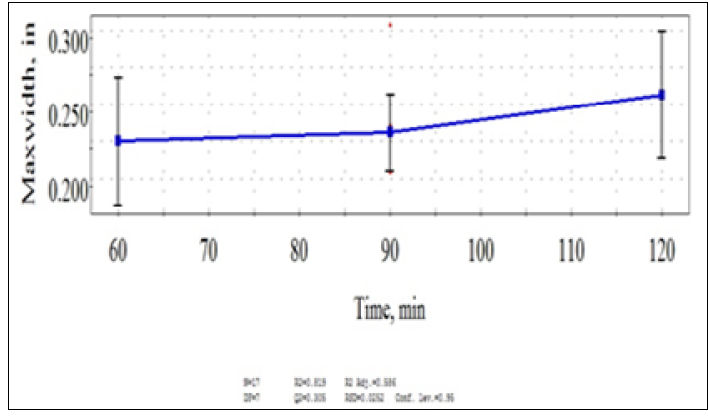

Fig. 9. The effect of the injection time on the fracture width

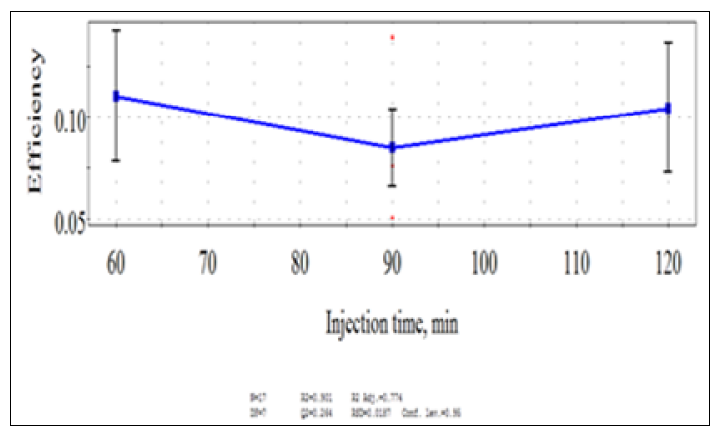

Fig. 10. The effect of the injection time on fluid efficiency

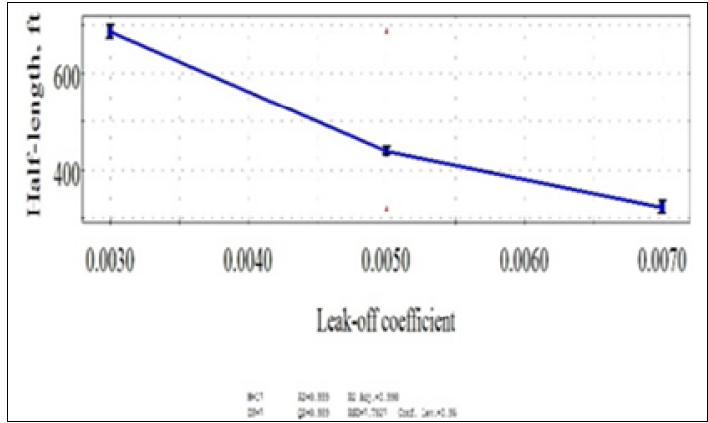

Fig. 11. The effect of the leak-off coefficient on fracture half-length

\section{THE EFFECT OF LEAK-OFF COEFFICIENT ON THE FRACTURE GEOMETRY}

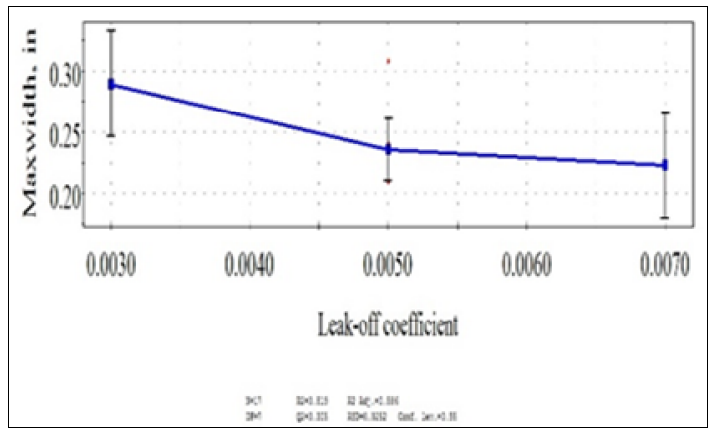

Fig. 12. The effect of the leak-off coefficient on fracture width

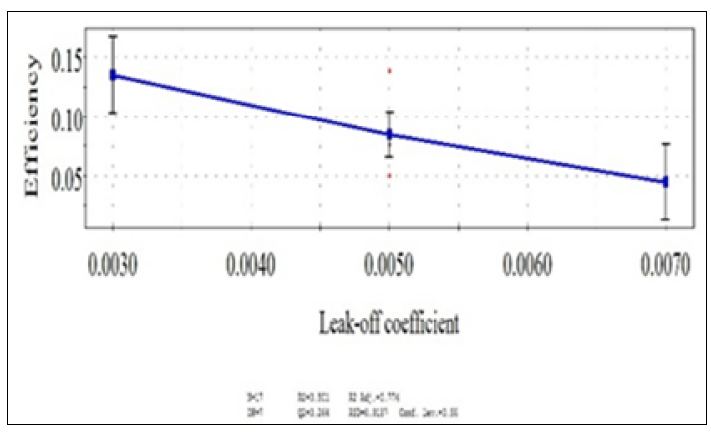

Fig. 13. The effect of the leak-off coefficient on the fluid efficiency

Figures 12 and 13 are present the effect of the leak-off coefficient on the fracture geometry. The figures explain when the leakoff coefficient $\mathrm{C}_{1}$ increases from $0.003 \mathrm{ft} / \mathrm{min}^{0.5}$ to $0.007 \mathrm{ft} / \mathrm{min}^{0.5}$, the fracture 
half-length decreases. Accordingly, the decrease of fracture half-length results in decrease of fracture width because fracture half-length is directly proportional to the fracture width as presented in figure 8 . This is because the increase of the leak-off coefficient leads to decrease of fracture half-length because leak-off coefficient is inversely proportional to fracture half-length as presented in figure 3. In another explanation, based on the material balance, the total injection rate $\mathrm{q}$ is equal to fracture volume and fluid volume loss among the fractures. Thus, the larger leak-off coefficient caues larger fluid volume loss. higher leak-off coefficient leads to more fluid volume loss to the fractures because the leak-off coefficient is proportional to the total fluid volume loss and thin fracture geometry as shorter fracture halflength. This is based on the 2D PKN fracture geometry in terms of the leak-off coefficient and power law parameters. Meanwhile proppant slurry is pumped into the well under high pressure based on the constant fracture height of $72 \mathrm{ft}$. Figure 13 presents the leak-off coefficient versus the fluid efficiency. The figure has shown when the leak-off coefficient increases from $0.003 \mathrm{ft} / \mathrm{min}^{0.5}$ to $0.007 \mathrm{ft} / \mathrm{min}^{0.5}$, the fluid efficiency decreases. This is because the larger leak-off coefficient results in more fluid volume loss into the area of the fractures. Meanwhile, the material balance is equal to the fracture volume plus the total fluid volume loss. Thus more total fluid volume loss brings to low fluid efficiency. Furthermore, the fluid efficiency is given by [15].

$$
\text { Fluid efficiency }=\frac{V_{f}}{V_{i}}=\frac{V i-V_{l}}{V_{i}}=1-\frac{V_{l}}{V_{i}}
$$

\section{CONCLUSIONS}

Through this research of design of experiments (DOE), that applies the operating parameters of hydraulic fracturing to evaluate the effect of parameters on the fracture geometry and fluid efficiency of using the 2D PKN-C fracture geometry model, the authors can summarize as follows.
The increase of the injection rate leads to increase of the fracture half-length and fracture width, and the gradual decrease of the fluid efficiency.

The increase of the injection time brings to increase of the fracture half-length, fracture width, and decrease of the fluid efficiency.

The higher leak-off coefficient results in narrower fracture width, shorter fracture halflength, and low fluid efficiency.

\section{REFERENCES}

1. Valk, P., and Economides, M. J., 1995. Hydraulic fracture mechanics. Wiley, New York.

2. Nguyen, D. H., and Bae, W., 2013. Design Optimization of Hydraulic Fracturing for Oligocene Reservoir in Offshore Vietnam. In IPTC 2013: International Petroleum Technology Conference.

3. Economides, M., Oligney, R., and Valkó, $P ., 2002$. Unified fracture design: bridging the gap between theory and practice. Orsa Press.

4. Perkins, T. K., and Kern, L. R., 1961. Widths of hydraulic fractures. Journal of Petroleum Technology, 13(9): 937-949.

5. Nordgren, R. P., 1972. Propagation of a vertical hydraulic fracture. Society of Petroleum Engineers Journal, 12(4): 306-314.

6. Howard, G. C., and Fast, C. R., 1957. Optimum fluid characteristics for fracture extension. In Drilling and production practice. American Petroleum Institute.

7. Rahman, M. M., and Rahman, M. K., 2010. A review of hydraulic fracture models and development of an improved pseudo-3D model for stimulating tight oil/gas sand. Energy Sources, Part A: Recovery, Utilization, and Environmental Effects, 32(15): 1416-1436.

8. Nolte, K. G., 1986. Determination of proppant and fluid schedules from fracturing-pressure decline. SPE Production Engineering, 1(4): 255-265.

9. Myers, R. H., Montgomery, D. C., and Anderson-Cook, C. M., 2016. Response surface methodology: process and product 
optimization using designed experiments. John Wiley \& Sons.

10. Williams, B. B., 1970. Fluid loss from hydraulically induced fractures. Journal of Petroleum Technology, 22(07): 882-888.

11. Williams, B. B., Gidley, J. L., and Schechter, R. S., 1979. Acidizing fundamentals. Henry L. Doherty Memorial Fund of AIME, Society of Petroleum Engineers of AIME.

12. Truong, N. H., Bae, W., and Nhan, H. T., 2016. Integrated Model Development for Tight Oil Sands Reservoir with 2D Fracture
Geometry and Reviewed Sensitivity Analysis of Hydraulic Fracturing. Research Journal of Applied Sciences, Engineering and Technology, 12(4): 375-385.

13. Meyer, 2014. Fracturing Simulation. Mfrac Software.

14. Smith, M. B., 1997. Hydraulic Fracturing. $2^{\text {nd }}$ Edn., NSI Technologies, Tulsa, Oklahoma

15. Economides, M. J., and Martin, T., 2007. Modern fracturing: Enhancing natural gas production (pp. 978-1). Houston, Texas: ET Publishing.

\title{
ẢNH HƯỞNG CỦA CÁC THÔNG SỐ VẬN HÀNH NƯ'T VỈA THỦY LỬC LÊN HİNH DÁNG NÚT VỈA VÀ HIỆU QUẢ NÚT VİA CHO TẦNG CHƯ'A OLIGOCEN TẠI VÙNG BIỄN VIẸT NAM
}

\author{
Nguyễn Hữu Trường \\ Trưòng Đại học Dầu khí Việt Nam
}

TÓM TĂT: Trong nhũng thập kỷ qua, một lượng lớn dầu được khai thác tại bồn trũng Cưu Long chủ yếu tù̀ tầng móng, và một lương nhỏ dầu được khai thác tại tầng chứa Miocen và tầng chứa dầu Oligocen. Nhiều giếng thăm dò và giếng khai thác thuộc Trà Tân và Trà Cú thuộc đối tượng Oligocen cát kết có tiềm năng chứa dầu khí tốt, tại đó đa số các vỉa chứa dầu có độ rông trung bình khoảng tù̀ $10 \%$ đến $18 \%$, và độ thấm của via chưa khoảng $0,1 \mathrm{md}$ đến $5 \mathrm{md}$. Do cấu trúc địa chất của các vỉa dầu khí bất đồng nhất và phức tạp ở đó áp suất đóng khe nứt lên đến 7.700 psi nhung cho lưu luợng khai thác dầu còn hạn chế. Vấn đề lớn của vỉa chứa dầu thuộc đối tuợng Oligocen là dẫn suất của các khe nứt trong vỉa chứa rất thấp do độ liên thông của các khe nứt trong via chứa dầu khí kém. Để giải quyết những thách thức lớn này cần phải kích thích vỉa dầu khí bằng nứt via thủy lực để khoi thông các khe nứt nhằm nâng cao lưu lượng khai thác. Trong bài viết này, tác giả trình bày ảnh hưởng của các thông số vận hành nứt vỉa thủy lực nhu thờ gian bơm nứt vỉa thủy lực, lưu luợng bơm, hệ số tốc độ mất dung dịch trên cơ sở mô hình $2 D P K N-C$, giới hạn bởi hệ số tốc độ mất dung dịch qua diện tích khe nưt, hệ số mất nuoớc Sp, và các thông số mô hình power law lên hình dáng của khe nưt, với thiết kế thí nghiệm cho ba thông số vận hành nứt via thủy lực dựa trên kinh nghiệm nưt via thưy lực cho các via dầu và áp dụng công cu phương pháp bề mạtt. Nhũng năm gần đây, việc áp dụng thành công công nghệ nứt via thủy lực để nhằm kích thích via cho các giếng khoan hoàn thiện thuộc đối tượng Oligocen để nâng cao lưu lương khai thác.

Tù̀ khóa: Thông số vận hành nứt via thủy lực, hình dáng nứt vỉa $2 D P K N-C$, hiệu quả nứt vỉa. 